\title{
Adaptation of California Measure of Mental Motivation -CM3
}

\author{
Hasan Fehmi Özdemir ${ }^{1}$, Nükhet Çıkrıkçı Demirtaşlı² \\ ${ }^{1}$ Continuing Education Centre, Ankara University, Ankara, Turkey \\ ${ }^{2}$ Faculty of Educational Sciences Department of Measurement and Evaluation, Ankara University, Ankara, Turkey \\ Correspondence: Hasan Fehmi Özdemir, Continuing Education Centre, Ankara University, Tandogan Kampusu, 06500, \\ Besevler, Ankara, Turkey
}

Received: August 5, 2015 Accepted: August 20, $2015 \quad$ Online Published: September 18, 2015

doi:10.11114/jets.v3i6.1006

URL: http://dx.doi.org/10.11114/jets.v3i6.1006

\begin{abstract}
Education without doubt, plays a vital role for individuals to gain the essential personal traits of the 21st century, also known as "knowledge age". One of the most important skills among these fundamental qualities which the individuals should be equipped with is critical thinking. California Measure of Mental Motivation-CM3 was developed by Giancarlo, Blohm \& Urdan (2004) to assess secondary school students' critical thinking dispositions which is one of the characteristic components of critical thinking. Detecting secondary school students' dispositions toward critical thinking is desired to be one of the main foci in many Turkish educational studies; however, it seems there is no Turkish psychological measurement instrument, assessing this feature among these age groups. Adapting this scale into Turkish culture will support the future studies on critical thinking by supplying a new instrument to the psychological measurement literature. The adaptation process has revealed that CM3 retains a four-factor structure in Turkish culture, similarly to the original form, and this structure has been confirmed by confirmatory factor analysis. In terms of the internal consistency, the Cronbach's alpha reliability values have appeared to be between the reference values based in the literature. Furthermore, the test-retest reliability analysis has exposed considerably high level and significant correlation.
\end{abstract}

Keywords: critical thinking, critical thinking disposition, secondary school students, scale adaptation, validity, reliability

\section{Introduction}

Today, the point where the production of the knowledge reached has brought along easy access to knowledge, knowing the ways of sharing and rapid utilization of it. This shift has caused 21 st century to be characterized as "knowledge age" and as an implification of this, some essential qualifications have come into prominence for individuals. Skills such as; establishing effective communication, behaving independently, collaboration, ability to use technology, researching, problem solving and decision-making, innovation, creative and critical thinking are considered as the most important ones among the rest.

The role of education of course is very important for individuals to gain these skills, and therefore education should be structured and has an aim to help individuals to reach this objective. When it is interpreted within this perspective, education should nurture self-aware, conscious about rights and responsibilities, thinking, questioning, sound, rationale decision-taking individuals who will contribute to social development and democratic life, support economic development and preserve and improve cultural values. However, it is claimed that conventional education systems up against the competitive structure of knowledge society have gradually lost their effects and become inadequate.

It is possible to meet several different explanations for critical thinking skill within the literature. American Philosophical Association states a concensus explaining that the cognitive skills; reasoning, analyse, interpretation, inference, explanation, evaluation and self regulation form the core of critical thinking (APA, 1990).

Critical thinking is the ability to integrate and use behaviours, attitudes and knowledge. It examines the supportive evidences which an individual uses to reach the consequences with a systematic manner, being able to link them logically and adapting them to new situations (Çıkrıkçı, 1993; Newfield, 1997; Watson \& Glaser, 1980).

Critical thinking is one of the higher order thinking skills. Cüceloğlu (1999) emphasizes the necessity in order to be able to reach critical thinking by personal development, an individual should recognize his/her own thinking process, direct 
his/her thoughts consciously, examine the thinking processes of the others and compare them with his/hers, also he/she would be able to use the previously learned knowledge in authentic situations in daily life.

Though cognitive skills forming critical thinking are important, they are inadequate to understand and explain critical thinking on their own. Critical thinking disposition which is one of the characteristic components of critical thinking has to be taken into consideration. Because, no matter how much the individuals possess these skills, they wouldn't have consistent internal motivation to use them. This can cause an incorrect interpretation as if the individuals are in lack of these skills. Individuals' willingness and their internal motivation to use these skills can be termed as "critical thinking disposition" and this term is the basis of critical thinking. Critical thinking disposition is an obligatory prerequisite for critical thinking skills and inseparable component of critical thinking capacity. Good critical thinking includes both a skill dimension and a dispositional dimension. Critical thinking is essential as a tool of inquiry. As such, it is a liberating force in education and a powerful resource in one's personal and civic life. Individuals who have developed effective dispositions are much more likely to apply their critical skills appropriately than those who have mastered the skills but are not disposed to use them. (APA, 1990; Facione, 1998; Facione et al., 1998; Giancarlo \& Facione, 2001).

Psychological tests are used in many fields of social sciences and medicine, particularly; psychology, education, sociology and psychiatry fields which study human behaviours. In general terms psychological tests measure and interpret psychological characteristics of individuals' competences, skills, performances, motivation, and attitudes and assist taking various decisions about individuals.

Studies on scales have always been an important component of psychological studies. Şahin (1994) has drawn attention to the large number of researches and publications on scales in Turkey which may be interpreted as an indicator of the importance and need for scales in Turkey.

There is a vast number of scales in Turkey which have been developed for various reasons. But, there is still a need for new scales assessing different psychological features which could be used for different target groups, age groups etc. Developing and/or adapting new scales would be an answer for this need. Test adaptation has advantages and benefits such as; sharing the technical information, building international collaborations and increase in the information exchange, localization of psychology, intercultural comperative studies, increase in the potential of gathering objective data in various topics, contribution to producing new information by being used in different studies (Azuma, 1984; Adair, Puhan \& Vohra, 1993; cited by Şahin, 1994).

Different scales were developed in order to assess both critical thinking skills and critical thinking dispositions, and some of these were adapted to Turkish culture such as; Watson-Glaser Critical Thinking Appraisal Test (Form YM) studied by Çıkrıkçı (1993), the short form of the same test was adapted by Yörük (2002). Both of these instruments assess critical thinking as a cognitive feature.

Reviewing the Turkish literature has shown that there seems to be no such a psychological measurement instrument, assessing 6th, 7th and 8th grade students' critical thinking dispositions exists in Turkey. Besides, critical thinking has been one of the primary skills of this century which has given another important reason for us to make this study.

The aim of this study is to adapt and investigate the applicability of California Measure of Mental Motivation-CM3 for secondary school 6th, 7th and 8th grade students as a psychological means of survey and determine the psychometric features (validity, reliability) of this scale for these groups. In this sense, adapting this tool into Turkish culture will support the future studies on critical thinking by supplying a new instrument to the psychological measurement literature.

\section{Method}

\subsection{Research Design}

This research is designed as a descriptive research. Its major aim is to adapt the California Measure of Mental Motivation-CM3, developed in the United States of America (USA) by Giancarlo, Blohm \& Urdan (2004), into Turkish culture by determining its psychometric features (validity, reliability). (Note 1)

\subsection{Adapted Scale and Its Features}

California Measure of Mental Motivation-CM3 was developed in the United States of America (USA) by Giancarlo, Blohm \& Urdan (2004) to assess 6-12 grade students' critical thinking dispositions.

The conceptualization of critical thinking, from which the CM3 was developed, is the one that recognizes a set of general, discipline-neutral cognitive processes that can be used to describe thinking, problem solving, and judgement. The CM3 is designed to measure the degree to which an individual is cognitively engaged and mentally motivated toward intellectual activities that involve reasoning. The CM3 targets four main dispositional aspects of critical thinking: open-mindedness, selfregulation, a commitment to learning and mastery, and creative problem solving (Giancarlo, 
Blohm \& Urdan, 2004).

Initial pilot investigation of CM3 was carried out on a total of 1378 students in grades 6 through 12, representing 19 school sites from 10 states of the USA. According to the factor analysis results which aims to explore the construct validity, the items carrying factor loading values less than .30 were eliminated, a 54 item scale appeared with four subscales which are, "Learning Orientation", "Creative Problem Solving", "Mental Focus" and "Cognitive Integrity" (Giancarlo, Blohm \& Urdan, 2004, p. 350).

After the pilot application investigating the stability of the four-factor structure of the CM3 through the use of confirmatory factor analysis, other validity and reliability studies were carried out. In order to shorten the application time, the number of the items was reduced from 54 to 25 (Giancarlo, Blohm ve Urdan, 2004).

In order to determine the validity of the CM3, three validity studies were performed. First, the CM3 scales were investigated in relation to previously validated measures of student motivation and behavior. Second, to evaluate the hypothesis that the disposition toward critical thinking is positively related to academic achievement, correlations between the CM3 scales and students' standardized test scores and grade point average were investigated. Last, to demonstrate the discriminant validity of the CM3, correlations with the Marlowe-Crowne Social Desirability Index are presented. During the development process the Cronbach's alpha reliability coefficients obtained from three different sample groups range between .53 and .83 .

CM3's first subscale "Learning Orientation" is defined as a disposition toward increasing one's knowledge and skill base. Valuing the learning process as a means to accomplish mastery over a task. Interested in challenging activities. Uses information seeking as a personal strategy when problem solving. The second subscale "Creative Problem Solving" is a disposition toward approaching problem solving with innovative or original ideas and solutions. Feeling imaginative, ingenious, original, and able to solve difficult problems. Desire to engage in activities such as puzzles, games of strategy, and understanding the underlying function of objects. The third subscale "Mental Focus" is explained as a disposition toward being diligent, systematic, task oriented, organized, and clearheaded. Feeling at ease with engaging in problem solving. Feeling systematic and confident in ability to complete tasks in timely way. Feeling focused and clearheaded. Last subscale "Cognitive Integrity" is a disposition toward interacting with differing viewpoints for the sake of learning the truth or reaching the best decision. The expression of strong intellectual curiosity. Valuing the fair-minded consideration of alternative perspectives (Giancarlo, Blohm \& Urdan, 2004).

\subsection{Scale Adaptation Process}

Assessment tools developed for measuring psychological features of a certain culture can be adapted into different cultures and languages. Increase in the demand for setting the differences between and comparing the national, ethnical and cultural groups have been the main aims of the scale adaptation process. Additionally, there is a growing international interest for taking common educational and psychological precautions by determining the abilities, skills and attitudes of the students belonging to different cultures and countries (Rapp ve Allalouf, 2003). An assessment tool developed in a specific culture carries the specific features of that culture. The systematic preparation process conducted for applying the scales to different cultures and languages is called scale adaptation (Öner, 1987). The aim of the adaptation process is to make the usage of measurement tools for specific cultures available for different cultures.

Hambleton and Patsula (1999) state the importance of knowing and following some steps to make an adaptation accurately. Below are the brief steps of adaptation process:

1. Step: Structural equality/equivalence should be assured in terms of language and culture

2. Step: Making the decision whether to develop a new inventory or adapt an existing one.

3. Step: Well-qualified translators should be chosen.

4. Step: The assessment tool should be translated and adapted to the target language.

5. Step: The adapted tool should be revised and amended if necessary.

6. Step: Lingual equality should be ensured between the original and the target language forms of the tool by applying to a bilingual group or to a group which has mastery in both languages and cultures.

7. Step: The adapted tool should be applied on a small bilingual group.

8. Step: After determining the validity and reliability of the tool and item analysis with the output of the pretest, the finalised form of the scale shoud be applied to a larger group that resembles the real group as in the original development process, and psychometric studies should be repeated like factor analysis to test the construct validity.

9. Step: Appropriate validity and reliability studies should be conducted. 
10. Step: Process of the adaptation should be reported in details and a handbook and/or instructions should be prepared for the users.

11. Step: Potential test givers should be trained.

12. Step: The tool should be kept up to date with the help of new studies.

The steps taken in this study while the scale "California Measure of Mental Motivation-CM3" was adapted into Turkish culture can be summarized as follows:

- In order to be able to start the adaption process, written permission and approval of the developers were recieved.

- Scale was translated into Turkish and then back-translation process was completed.

- Both the translation and back-translation processes have been carried out with different translators. It is paid strict attention to form both of the groups from the translators who have a good command of English, and who have knowledge about test development and critical thinking subjects.

- The original, Turkish and the back-translation forms were presented to a group of five experts. They were asked to compare all three forms in terms of language and meaning. In accordance with the experts' opinions, corrections were made and a final control was conducted by Turkish language experts. Also after the revisions, the back-translation form was sent to one of the developers, Dr. Giancarlo, and her approval was received.

- Scale was administered to the small group of students who have a good command of both languages with an aim to assess equivalence and understandability of the language. Correlation between the datas obtained from both forms, was computed. Scale was revised one more time with the help of the feedback taken from this group.

- The finalized Turkish form was administered to the students in the study group. Both before and after the administration process the points which have vital importance for the study were paid attention such as; introducing the scale to test takers, examining and determining the students who do not show willingness to complete the scale, and keeping their answers outside the analysis.

- According to the collected data from this group, the factor structure of the scale in Turkish culture was explored. And also reliability studies were carried out.

- After technical features identified, the scale was administered to a group of 130, 6th, 7th and 8th grade students. The data collected from this group were used to find out whether the factor structure confirmed with Confirmatory Factor Analysis.

- Final form was generated in accordance with all the findings.

\subsection{Application/Study Groups}

Three different study groups were used in the scale adaptation process. They are as follows respectively:

\subsubsection{Lingual Equivalence Testing Group}

This study group was the application group in which the lingual equivalence of the original and Turkish forms was tested. It consists of 70 students attending 7th and 8th grades at the Ankara University Development Foundation School.

\subsubsection{Factor Structure Exploration Group}

This study group was application group in which the linguistically equivalent scale's factor structure in the Turkish culture was explored. And also the reliability studies were carried out. It consists of 1000 students attending 6-8 grades in state schools.

\subsubsection{Factor Structure Confirmation Study Group}

This study group consists of 130 students attending 6-8 grades in state schools.

\subsection{Data Analysis}

Data collected from the study were analyzed through IBM-SPSS 22 and AMOS packet programs. Techniques used to determine validity and reliability were Kaiser-Meyer-Olkin (KMO) test, Bartlett Sphericity test, varimax rotation, anti-image correlation, Cronbach's alpha reliability coefficient, exploratory and confirmatory factor analysis (Büyüköztürk, 2003; Özdamar, 2013). Details of the analysis are given in 'results' section.

\section{Results}

\subsection{Lingual Equivalence}

In order to determine the consistency between Turkish and English forms of the adapted scale, both forms were administered to a group of 70 students who have a good command of both languages and cultures. The data obtained 
from these applications were transformed into total scores both in terms of the entire scale and its subscales. Total scores obtained from subscales and entire scales were examined by means of Pearson's Product Moment Correlation Coefficient between Turkish and English forms. Analyzing the correlation by using this technique prerequires the normal distribution of the data sets (Green ve Salkind, 2008; Kalayc1, 2005; Özdamar, 2013; Warner, 2008). Normal distribution was tested by the "Kolmogorov-Smirnov Test". According to the test results, total score of the entire scale; as well as Creative Problem Solving, Learning Orientation, Mental Focus and Cognitive Integrity subscales' scores were normally distributed ( $\mathrm{p}>.05$ ). Consequently, the correlation between the applications were examined with "Pearson Product Moment Correlation Coefficient" and the correlational results are given in Table 1.

Table 1. Lingual Equivalence Correlations

\begin{tabular}{lccc}
\hline \multicolumn{1}{c}{ Turkish Form * Original Form } & $\mathrm{N}$ & $\mathrm{r}$ & $\mathrm{p}$ \\
\hline Total Scores & 70 & .922 & .000 \\
Creative Problem Solving subscale scores & 70 & .902 & .000 \\
Learning Orientation subscale scores & 70 & .813 & .000 \\
Mental Focus subscale scores & 70 & .781 & .000 \\
Cognitive Integrity subscale scores & 70 & .827 & .000 \\
\hline
\end{tabular}

Table 1 shows that there is a positive, high level and significant correlation between total scores of Turkish and English forms, as well as scores of Creative Problem Solving, Learning Orientation, Mental Focus and Cognitive Integrity subscales $(\mathrm{r}=0.916,0.969,0.877,0.721,0.827$ and $0.699, \mathrm{p}<.05)$. Thus, it can be said that there is a lingual equivalency and consistency between Turkish and original forms.

\subsection{Construct Validity (Factor Analysis) and Reliability}

In order to investigate the construct validity of the scale, exploratory factor analysis was used for the data collected from a total number of 1000 6th, 7th and 8th grade students. KMO value was examined and found .84 . According to the relevant literature (Büyüköztürk, 2013; Özdamar, 2013), KMO value needs to be over .50 which is a threshold value to determine whether the data set is appropriate for the factor analysis. The result obtained from Bartlett Test serving to the same purpose was found as $\left[\chi^{2}=3632.521 ; \mathrm{p}<0.01\right]$. Both values were significant, which means factor analysis could be conducted for the data set.

Before all else the Kaiser-Guttman method was used to decide the number of the factors of CM3's adapted form's structure (Nunnally \& Bernstein, 1994). According to this method the number of the factors having an eigenvalue over 1.00 was found to be 5 . But when the scree plot was examined it was decided that the factor number should be 4 . For this reason the number of the factors was fixed to 4 and the analysis was completed. The scree plot graphic can be seen in Figure 1.

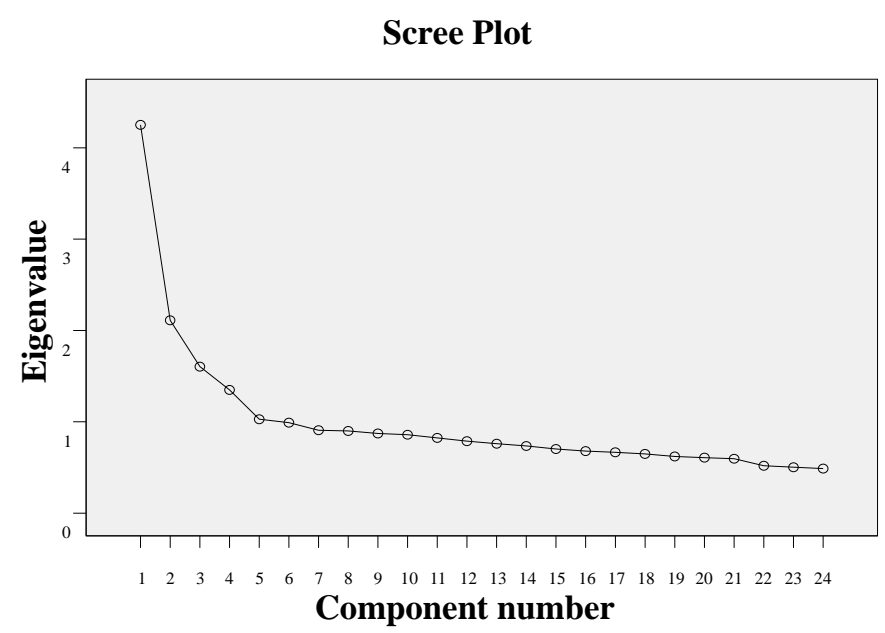

Figure 1. Scree Plot displaying the factor number of adapted Turkish form of CM3

While conducting exploratory factor analysis Varimax rotation technique was applied, in order to decide whether there are any subscales, and if there are, which items are aggregated under which subscales (Büyüköztürk, 2013; Özdamar, 2013). Varimax rotation results are given in Table 2.

When the factor analysis results of the CM3 Turkish form are examined, the Turkish form appears to have a four-factor structure, similar to the original form. However, in Turkish form the orders of the first and second factors have changed, one item which appears to be loaded under more than one factor was removed from the scale and some items relocated 
within the factors.

Table 2. Turkish Form's Factor Analysis Results after Varimax Rotation

\begin{tabular}{|c|c|c|c|c|}
\hline Item No & $\begin{array}{l}\text { Factor } \\
\text { I }\end{array}$ & $\begin{array}{l}\text { Factor } \\
\text { II }\end{array}$ & $\begin{array}{c}\text { Factor } \\
\text { III }\end{array}$ & $\begin{array}{c}\text { Factor } \\
\text { IV }\end{array}$ \\
\hline 2 & .57 & & & \\
\hline 7 & .72 & & & \\
\hline 8 & .58 & & & \\
\hline 9 & .40 & & & \\
\hline 10 & .36 & & & \\
\hline 11 & .56 & & & \\
\hline 12 & .59 & & & \\
\hline 1 & & .60 & & \\
\hline 4 & & .61 & & \\
\hline 5 & & .52 & & \\
\hline 6 & & .63 & & \\
\hline 17 & & .52 & & \\
\hline 18 & & .53 & & \\
\hline 13 & & & .45 & \\
\hline 14 & & & .72 & \\
\hline 15 & & & .71 & \\
\hline 16 & & & .53 & \\
\hline 19 & & & .37 & \\
\hline 20 & & & .48 & \\
\hline 21 & & & & .49 \\
\hline 22 & & & & .59 \\
\hline 23 & & & & .66 \\
\hline 24 & & & & .59 \\
\hline 25 & & & & .62 \\
\hline Number of Items (k) & 7 & 6 & 6 & 5 \\
\hline Variance explained \% & 10.55 & 9.89 & 9.37 & 9.01 \\
\hline
\end{tabular}

Instead of "Learning Orientation", which was the first factor of the original form, "Creative Problem Solving" has captured the most variance explained in Turkish form. In other words, one of the main differences between the original and Turkish forms is the change of the first and second factors' orders. Also the 2nd item of the original form, "I always look forward to learning challenging things." relocates under the "Creative Problem Solving" factor in Turkish form. Thus, there appears to be 7 items in the first factor with factor loading values between .36 and .72, and item-total correlations range from .20 to .42 . The total variance explained by this factor is $10.55 \%$.

As previously mentioned, the first factor of the original form "Learning Orientation" appeared as the second factor in the Turkish form. In addition to the first six items, those of which constitute this factor in the original form, two more items "It is difficult for me to finish my school assignments. (Item 17)" and "I keep my schoolwork organized. (Item 18)" located in the Turkish form distinctively. "Being eager to learn about different things is one of my strong points. (Item 3)" was decided to be removed from the scale due to the high values it has shown under more than one factor. The 2nd item of the original form, "I always look forward to learning challenging things. (Item 2)", is relocated under the second factor "Learning Orientation" in Turkish form. There are 6 items in this factor and their factor loading values change from .52 to .63 , and item-total correlations range from .20 to .42 . The total variance explained by this factor is $9.89 \%$.

In the original form, the items 14 to 20 appear under the third factor, "Mental Focus". But in the Turkish form on the other hand, the item 13 "I am one of the smartest kids in my class." also moved into this factor. In addition to this change, originally third factors' items $17 \& 18$ relocated under the second factor as mentioned above. In this respect, 6 items are located in this factor with factor loading values between .37 and .72 , and item-total correlations range from .29 to .41 . The total variance explained by this factor is $9.37 \%$.

The fourth factor of the original scale "Cognitive Integrity", consists of the same items in both original and Turkish forms. The varimax rotated factor loading values of this factor's items 21 to 25 are ranging from .49 to .66 . The item-total correlations of these five items are between .14 and .37. The total variance explained by this factor is $9.01 \%$. Four factors together account for $38.81 \%$ of the total variance.

In the light of the results of the exploratory factor analysis of the Turkish form were examined, it can be said that there is a similarity between the two forms in general. Eventhough the orders of two factors have changed and some items have relocated within the factors, still it can be concluded that the factor structure has been appeared similar in the Turkish form. And, just one disfunctional item was removed from the scale. 
In order to find out whether the subscales of the original and Turkish forms are similar, the correlation coefficients between the factors of Turkish form were computed. These coefficients are given in Table 3 with the correlation coefficients obtained from two different studies in the development process of the original scale.

Table 3. Correlations between the subscales of CM3's Original and adapted Turkish Forms

\begin{tabular}{|c|c|c|c|c|c|c|}
\hline $\begin{array}{c}\text { California Measure of Mental } \\
\text { Motivation - CM3 }\end{array}$ & Forms & Study & $\begin{array}{l}\text { Learning } \\
\text { Orientation }\end{array}$ & $\begin{array}{c}\text { Creative } \\
\text { Problem } \\
\text { Solving }\end{array}$ & Mental Focus & Cognitive Integrity \\
\hline \multirow{3}{*}{ Learning Orientation } & \multirow{2}{*}{ Original Form } & 1 & - & $.59 * *$ & $.40 * *$ & $.15^{* *}$ \\
\hline & & 2 & - & $.64 * *$ & $.42 * *$ & $.40 * *$ \\
\hline & Turkish Form & - & - & $.41 * *$ & $.32 * *$ & $.20 * *$ \\
\hline \multirow{3}{*}{ Creative Problem Solving } & \multirow{2}{*}{ Original Form } & 1 & $.64 * *$ & - & $.45^{* *}$ & $.18 * *$ \\
\hline & & 2 & $.59 * *$ & - & $.48^{* *}$ & $.33 * *$ \\
\hline & Turkish Form & - & - & - & $.39 * *$ & $.15^{* *}$ \\
\hline \multirow{3}{*}{ Mental Focus } & \multirow{2}{*}{ Original Form } & 1 & $.42 * *$ & $.48 * *$ & - & $.26 * *$ \\
\hline & & 2 & $.40 * *$ & $.45^{* *}$ & - & $.28 * *$ \\
\hline & Turkish Form & - & - & - & - & $.24 * *$ \\
\hline \multirow{3}{*}{ Cognitive Integrity } & \multirow{2}{*}{ Original Form } & 1 & $.40 * *$ & $.33 * *$ & $.28 * *$ & - \\
\hline & & 2 & $.15^{* *}$ & $.18 * *$ & $.26 * *$ & - \\
\hline & Turkish Form & - & - & - & - & - \\
\hline
\end{tabular}

When the coefficients given in Table 3 are compared, all the correlations both in the two studies of the original form and the Turkish form are considered statistically significant at the .01 level, and for an over-all comparison it can be said that the correlations of the original form are higher than the Turkish form's.

Cronbach's alpha internal consistency coefficients of subscales and the entire Turkish form are given in Table 4.

Tablo 4. CM3 Turkish Form's Cronbach's Alpha Internal Consistency Coefficients

\begin{tabular}{lcc}
\hline \multicolumn{1}{c}{ Subscales } & $\begin{array}{c}\text { Number of the } \\
\text { Items }(\mathrm{k})\end{array}$ & $\begin{array}{c}\text { Cronbach's Alpha Internal Consistency } \\
\text { Coefficients }(\alpha)\end{array}$ \\
\hline Learning Orientation & 7 & .63 \\
Creative Problem Solving & 6 & .66 \\
Mental Focus & 6 & .64 \\
Cognitive Integrity & 5 & .60 \\
$\quad$ Entire Scale & 24 & .78 \\
\hline
\end{tabular}

When the Table 4 is examined, Cronbach's alpha coefficients of the four subscales range from .60 to .66, which can be interpreted that the values are lower than in the original form. Also consistent with the original form, "Cognitive Integrity" subscale has the lowest value of all. Cronbach's alpha internal consistency coefficient for the entire scale is .78.

Next step of the study after the exploratory factor analysis was confirmatory factor analysis (CFA). It was carried out to determine whether the construct of the scale is confirmed or not. The model obtained as a result of the analysis is given in Figure 2. 


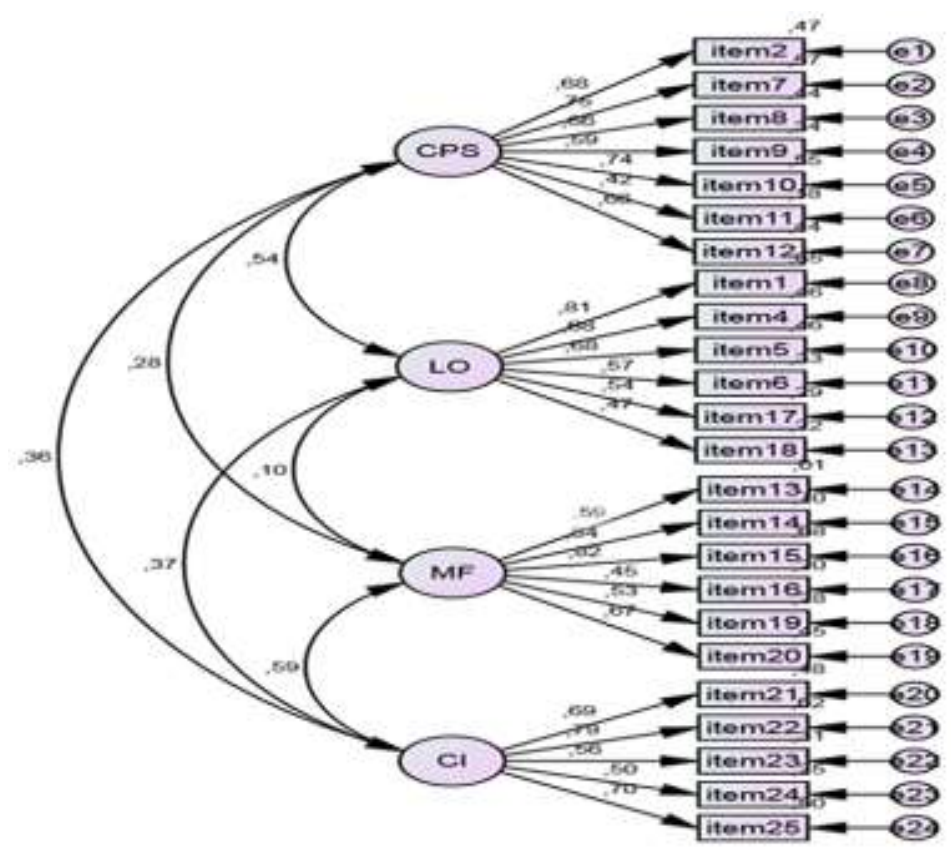

Figure 2. The Model of Confirmatory Factor Analysis based on the CM3 Turkish Form (Standardized values)

Figure 2 shows that the values of Chi-square and degree of freedom obtained from the Confirmatory Factor Analysis $(\mathrm{CFA})$ are $\chi 2=423.072,(\mathrm{sd}=246, \mathrm{p}<.01)$, and $\chi 2 / \mathrm{sd}$ ratio is 1.756 , which is an indicator of perfect fit. When this ratio reached from the selected samples is less than 3, this can be interpreted as there is a perfect fit (Jöreskog ve Sörbom, 1993; Sümer, 2000; Kline, 2005). In this adaptation study it can be asserted that there is almost a perfect fit between the model obtained from CFA and the data.

It can be said that one of the most widely used indices in CFA is root mean square error of approximation (RMSEA). In CFA, it is the sign of good fit of model and the data when RMSEA index is below .05 or lower; however, it is also stated that this value can be acceptable till .08 (Browne \& Cudeck, 1993; Hu \& Bentler, 1999; Şimşek, 2007; Vieira, 2011). In this study, RMSEA is .0621 which can be interpreted as an acceptable value.

In CFA, obtaining an AGFI (Adjusted Goodness of fit index) value more than 0.80, a RMR (Root- mean-square residual) value less than 0.10 (Anderson and Gerbing, 1984; Marsh, Balla and McDonald, 1988), and an SRMR (Standardized RMR) value less than 0.08 (Simsek, 2007) can be considered acceptable for confirming the model-data fit. The result of CFA determines AGFI as 0.87, RMR as 0.064 and SRMR as 0.054. Based on these results it can be asserted that the model-data fit is acceptable.

In CFA, when the Comparative Fit Index (CFI), Normed Fit Index (NFI) and Incremental Fit Index (IFI) values are .95 and above, this is a sign of perfect model-data fit (Bentler, 1990; Hu \& Bentler, 1999; Sümer, 2000; Şimşek, 2007; Çokluk, Güçlü \& Büyüköztürk, 2010). As a result the following indices were found and also given in Table 3; CFI is .951, NFI is .902 and IFI is .910. Based on these results it can be asserted that the model-data fit is acceptable.

Table 5. The goodness of fit values obtained from CFA

\begin{tabular}{lcccccc}
\hline$\chi^{2}$ & sd & $\chi 2 / s d$ & RMSEA & CFI & NFI & IFI \\
\hline 423.072 & 246 & 1.756 & .0621 & .951 & .902 & .910 \\
\hline
\end{tabular}

The main aim of CFA is to determine the goodness of fit between a previously defined model and obtained data (Sümbüloğlu \& Akdağ, 2009). In this respect, the four-factor structure of the adapted form of the California Measure of Mental Motivation - CM3 is confirmed according to the fit values gathered from CFA.

\subsection{The Findings of Test-Retest Reliability of CM3 Turkish Form}

In order to test the consistency of the scores obtained from two separate applications, the Turkish form of CM3 was administered to 105 students for the second time after a five week interval from the first application. Between these two applications a high level, significant and positive correlation was found $[\mathrm{r}=.73, \mathrm{P}<.01]$. Thus, it can be said that the adapted form of CM3 gives stable and reliable results.

\section{Discussion}

In this study, Measure of Mental Motivation-CM3, (Giancarlo, Blohm \& Urdan, 2004) was adapted into Turkish culture. In the original form of the scale, there are six items in "Learning Orientation" factor (first 6 items), seven items in each 
of the factors "Creative Problem Solving" (items 7 to 13) and "Mental Focus" (items 14 to 20). The last factor "Cognitive Integrity" consist of the last five items of the scale (items 21 to 25).

The following lines are the results obtained in accordance with the adaptation of the scale into Turkish culture:

- Adapted form of the scale, similar to the original form has a four-factor structure. However, it is identified that in Turkish form the orders of the first and second factors have changed. Besides, one item which has a high load value in more than one factor was removed from the scale and some items relocated between the factors.

- The relations between the original and Turkish forms' subscales have been compared. The result of this comparison revealed that all correlations between the subscales are statistically significant at the .01 level.

- Cronbach's alpha internal consistency coefficients of the four subscales range from .60 to .66, which can be interpreted as the values are lower than in the original form. Also it is consistent with the original form that the "Cognitive Integrity" subscale has the lowest value when compared to the other subscales. Cronbach's alpha internal consistency coefficient for the entire scale is .78.

- As further evidence for the reliability of CM3, test-retest reliability was obtained with a group of 105 . Between the two applications of the adapted form a high level, significant and positive correlation was explored $[\mathrm{r}=.73, \mathrm{P}<.01]$. This finding shows that the test-retest reliability is adequately high.

- This study has revealed in the light of psychometric data obtained from both the pilot application, which was provided for the lingual equivalence and the empirical application, the scale gives valid and reliable measures at an acceptable level.

In this study, the scale-CM3 was adapted for 6th, 7th and 8th grade students. The adaptation for upper grade students up to 12th grades can also be implemented. In subsequent studies it would be useful to study CM3's relations with the other scales measuring various psychological features and to reveal different validity and reliability evidences such as concurrent and predictive validity and two-half reliability etc. Besides, evidences of validity and reliability can also be obtained from different samples or study groups or with the data which can be collected from different types of secondary schools.

\section{Contributions}

This study has been generated from the master's thesis named "Adaptation of California Measure of Mental Motivation-CM3" which was submitted by Hasan Fehmi Özdemir under the supervision of Nükhet Çıkrıkçı Demirtaşlı at Ankara University, Institute of Educational Sciences.

\section{Acknowledgments}

There are many people I would like to thank who have supported and encouraged me throughout my thesis and to write this paper: Prof. Dr. Nükhet ÇIKRIKÇI DEMIRTAŞLI, Prof. Dr. Nizamettin KOÇ, Prof. Dr. Selahattin GELBAL, Prof. Dr. Ali DÖNMEZ, Prof. Dr. Figen ÇOK, Prof. Dr. Selahiddin ÖĞÜLMÜş, Assoc. Prof. Dr. Ömay ÇOKLUK, Adem TÜREDİ, Çetin TORAMAN and my beloved wife Esengül ÖZDEMIR.

\section{References}

Adair, J. G., Puhan, B. N., \& Vohra, N. (1993). Indegenization of psychology: Empirical assessment of progress in Indian research. International Journal of Psychology, 28, 149-169. http://dx.doi.org/10.1080/00207599308247182

American Philosophical Association, (1990). Critical thinking: A statement of expert concensus for purposes of educational assessment and instruction. Delphi Report Executive summary. Eric Document No: 315-423. https://assessment.trinity.duke.edu/documents/Delphi_Report.pdf

Azuma, H. (1984). Psychology in a non-western country. International Journal of Psychology, 19, 45-55. http://dx.doi.org/ 10.1080/00207598408247514

Bentler P. M. (1990). Comparative fit indexes in structural models. PsycholBull, 2(107), 238-246.

Browne M. W., \& Cudeck R. (1989). Single sample cross-validation indexes for covariance structures. Multivariate Behavioral Research, 24(4), 445-455. http://dx.doi.org/10.1207/s15327906mbr2404_4

Büyüköztürk, Ş. (2013). Sosyal bilimler için veri analizi el kitabı. Ankara: Pegema Yayınları.

Çokluk, Ö., Şekercioğlu, G., \& Büyüköztürk, Ş. (2010). Sosyal bilimler için çok değişkenli istatistik. Ankara: Pegem Akademi.

Cüceloğlu, D. (1999). İyi düşün doğru karar ver (30th Ed.). İstanbul: Sistem Yayıncılık.

Çıkrıkçı, N. (1993). Watson-Glaser Eleştirel Akıl Yürütme Gücü Ölçeğinin (Form YM) Lise Öğrencileri Üzerindeki Ön 
Deneme Uygulaması. Ankara Üniversitesi Eğitim Bilimleri Fakültesi Dergisi, 25(2), 559-569.

Facione, P. A. (1998). Critical thinking: What it is and why it counts? www.insightassessment.com/pdf_files/what\&why98.pdf

Facione, P. A., Facione, N. C., \& Giancarlo, C. A. (1998). Professional Judgement and the disposition toward critical thinking. http://www.calpress.com/pdf_files/skills_disp.PDF

Giancarlo, C. A., \& Facione, P. A. (2001). A look across four years at the disposition toward critical thinking among undergraduate students. The Journal of General Education, 50(1), 29-55. http://dx.doi.org/10.1353/jge.2001.0004

Giancarlo, C. A., Blohm, S. W., \& Urdan, T. (2004). Assessing secondary students' disposition toward critical thinking: Development of the California Measure of Mental Motivation. Educational and Pschological Measurement, 64(2), 347-364. http://dx.doi.org/ 10.1177/0013164403258464

Green, S. B., \& ve Salkind, N. J. (2008). Using SPSS for Windows and Macintosh (Analyzing and Understanding DataFifth Edition). New Jersey: Pearson Prentice Hall

Hambleton, R. K., \& Patsula, L. (1999). Increasing the validity of adapted tests: Myths to be avoided and guidelines for improving test adaptation practices, 1, 2. http://www.testpublishers.org.journal.html

Hu, L. T., \& Bentler P. M. (1999). Cut off criteria for fit indexes in covariance structure analysis: conventional criteria versus new alternatives. Structural Equation Modeling: A Multidisciplinary Journal, 1(6), 1-55. http://dx.doi.org/ $10.1080 / 10705519909540118$

Jöreskog, K. G., \& Sörbom, D. (1993). Lisrel 8: Structural Equation Modeling With the Simplis Command Language. Hillsdale: Erlbaum Associates Publishers.

Kalaycı, Ş. (2005). SPSS Uygulamalı Çok Değişkenli İstatistik Teknikleri. Ankara: Asil Yayın Dağıtım

Kline, R. B. (2005). Principles and Practice of Structural Equation Modeling. NewYork: The Guilford Press.

Newfield, T. (1997). Fostering critical inquery in classrooms. Kendai Net. 4.

Nunnally, R. C., \& Bernstein, I. H. (1994). Psychometric theory. New York: McGraw-Hill Inc.

Öner N. (1987). Kültürlerarası ölçek uyarlamasında bir yöntem bilim modeli. Türk Psikoloji Dergisi, 6(21), 80-83.

Özdamar, K. (2013). Paket programlar ile istatistiksel veri analizi (9th Ed.). Eskişehir: Nisan Kitabevi, 1.Cilt.

Özdamar, K. (2013). Paket programlar ile istatistiksel veri analizi (9th Ed.). Eskişehir: Nisan Kitabevi, 2. Cilt.

Rapp, J., \& Allalouf, A. (2003). Evaluating Cross-Lingual Equating. International Journal of Testing, 3(2), 101-117. http://dx.doi.org/ 10.1207/S15327574IJT0302_1

Sümer, N. (2000). Yapısal Eşitlik Modelleri: Temel Kavramlar ve Örnek Uygulamalar. Türk Psikoloji Yazıları, 6(3), 49-73.

Sümbüloğlu, K., \& Akdağ, B. (2009). İleri biyoistatistiksel yöntemler. (1st Ed.). Ankara: Hatipoğlu.

Şahin N. (1994). Psikoloji araştırmalarında ölçek kullanımı. Türk Psikoloji Dergisi, 9(33), 19-26.

Şimşek, Ö. F. (2007). Yapısal eşitlik modellemesine giriş: Temel ilkeler ve LISREL uygulamaları. İstanbul: Ekinoks Yayınları.

Vieira A. L. (2011). Preparation of theanalysis. Interactive LISREL in practice. (First Edition). London: Springer. http://dx.doi.org/10.1007/978-3-642-18044-6

Warner, R. M. (2008). Applied Statistics, From Bivariate Throug Multivariate Techniques. USA: Sage Publications, Inc. Watson, G., \& Glaser, E. M. (1980). Manual: The Watson-Glaser critical thinking appraisal. New York: Harcourt Brace.

Yörük, E. D. (2002). Watson-Glaser Eleştirel Akıl Yürütme Gücü Ölçeği'nin (Form S) Türkçe’ye uyarlama çalışması. (Unpublished master's thesis). Ankara Üniversitesi Eğitim Bilimleri Enstitüsü, Ankara.

\section{Notes}

Note 1. Both the original and adapted forms of CM3's all rights belong to Insight Assessment Company. www.insightassessment.com

\section{$(\mathrm{Cc}) \mathrm{BY}$}

This work is licensed under a Creative Commons Attribution 3.0 License. 